\title{
Public Administration Activities in the Light of the Contemporary Conception of Public Business Law ${ }^{1}$
}

\author{
Reflections on Contemporary \\ Dilemmas in Public Business Law
}

The conception of public business law in the Polish legal system has been shaped through an evolutionary process. Its origins can be found in the industrial law ${ }^{2}$ that became separate under administrative law and in pressing pre-war legal issues concerning state and local self-government enterprises (public enterprises). ${ }^{3}$ These issues were driven by spe-

1 Translated from: T. Rabska, Działania administracji publicznej w świetle współczesnej koncepcji publicznego prawa gospodarczego, in: Instrumenty i formy prawne działania administracji gospodarczej, B. Popowska, K. Kokocińska, Poznań 2009, pp. 15-34 by Stephen Dersley. The translation and proofreading were financed by the Ministry of Science and Higher Education under 848/2/P-DUN/2018.

2 Eg. T. Bigo, Prawo administracyjne polskie - prawo przemysłowe, Lwów 1939; T. Bigo, Ewolucja prawa przemysłowego, "Państwo i Prawo” 1947, no. 6-7; M. Zimmermann, Nauka administracji i polskie prawo administracyjne, Part II, Poznań 1949, in particular Chapter II Administracja przemysłu i handlu, p. 15 ff. Earlier: J. Buzek, Administracja gospodarstwa społecznego. Wykłady z zakresu nauki administracji i austriackiego prawa administracyjnego, Lwów-Warszawa 1913; numerous articles from scientific journals from the pre-war period. In Reglamentacja prawna i administracyjna stosunków gospodarczych, "Ruch Prawniczy, Socjologiczny i Ekonomiczny” 1922, facsim. 4, L. Caro wrote: “The state cannot be limited to the tasks of the night guard; of course, it should include all those areas in which the interest of the individual is contrary to the general interest, and where the action of the individual does not pay off, and which, for the reasons above, is not to be left out.” The leading position in Western legal science was taken by the book: E. R. Huber, Wirtschaftsverwaltungsrecht, vol. 1-2, Tubingen 1953/1954.

3 L. W. Biegeleisen, Teoria i polityka przedsiębiorstw publicznych samorzq̨du terytorialnego i państwa, Warszawa 1931; B. Helczyński, Komercjalizacja przedsiębiorstw państwowych na tle polskich przepisów prawnych, Warszawa 1929. 
cific economic needs and hence it became necessary for the distinction to be reflected in law. At the same time, this process also led to the construction of a new basis for the law.

In Poland, further legal development of this legal sphere was brought to a sudden halt due to the wartime occupation, and as a result of total reconstruction of the socio-economic system after the war, which affected the nature of this branch of law. Economic relations, however, always required that special regulations be subordinate to the changes taking place, taking into account both political assumptions and the economic system.

As a special object of reference, the economy, with all its determinants, has influenced and decisively influences the choice of legal mechanisms specific to this particular field, which deviate from the regulation of other social relations. This is reflected in the selection of different legal institutions, in the structures of organization, and the emergence of new forms of action (legal acts) of state organs. The basis for these are: changing constitutional norms ${ }^{4}$, ordinary statutes ${ }^{5}$, and executive acts, which in their entirety determine the legal character of not only individual acts (various types of decisions, contracts, agreements, etc.), but also general ones, made by the public administration within the framework of this administration, in contacts with economic entities, as well as in cooperation with non-governmental and social organizations.

As a consequence, public business law, which undoubtedly reflects the various changes taking place, had to undergo frequent changes in

4 It is quite characteristic that neither the Constitution of 1921 nor of 1935 contained any provisions defining the economic system of Poland. The Constitution of the Polish People's Republic (PRL), in rejecting the prevailing economic system, introduced a centrally managed state economy (Article $7 \mathrm{ff}$.) with all of the negative consequences this entailed. V. Konstytucje Rzeczypospolitej, ed. J. Boć, Wrocław 1998. In 1989, the rejection of the system formally introduced in 1952 required new constitutional regulation.

5 Only in terms of the sphere of undertaking business activities, see further changes to the legal basis: the President's ordinance of June 71927 on Industry Law, the Act of December 231988 on Economic Activity, the Act of November 19 1999 - The Law on Business Activity, the Act of July 22004 on the Freedom of Economic Activity as amended, and further draft changes. 
its content and scope. At the same time-within the system of lawthe borders and mutual relations between particular branches of law in the regulation of economic relations are outlined in different ways. In particular, this applies to the relationship between public law and private law. ${ }^{6}$ The overlapping of these legal norms in economic matters is also characteristic. ${ }^{7}$ Public law itself is not uniform in its structure, in the sense that it includes both systemic legal norms, norms of substantive business law, as well as specific procedural norms.

All these dilemmas affect the nature of public business law and determine scholarly interests, the scope and methods of analyzing phenomena, and research methods. It is also necessary to refer to the causes of legal solutions, which in turn requires reference to non-legal sciences.

From the historical perspective, one can treat theoretical discussions on public business law as a separate branch of the current system of the law in force. ${ }^{8}$ The specific stages of shaping its foundations were influenced above all by further fundamental changes related to the reconstruction of the country's political and economic system ${ }^{9}$. However, analysis of such changes lies beyond the scope of this study.

Currently, in the system of law in force, the position of public business law is well-established, as is evident from its place in legal science and university didactics, and from forms of institutionalization (inde-

6 The division of law into public and private spheres was only restored in legal science after the transformation of the political system in 1989.

$7 \mathrm{~V}$. in particular M. Safjan who, raising the problem of the interpenetration of public and private law regulations, states that in a number of areas "private and public law elements are very strongly intertwined”. V. System prawa prywatnego. Prawo cywilne. Część Ogólna, ed. M. Safjan, Warszawa 2007, p. 49.

8 From the extensive literature of the past period see in particular discussion in: Co jest prawo gospodarcze, "Ruch Prawniczy, Socjologiczny i Ekonomiczny” 1995.

9 From the formal-legal point of view, the limit of the new system is set by the Constitutional Amendment Act of 29 December 1989 (JL RP 1989, No. 75, item 444) and its Article 6: "The Republic of Poland guarantees the freedom of economic activity regardless of the form of ownership; restriction of this freedom can only take place in the act”. 
pendent chairs or departments). ${ }^{10}$ This is clearly confirmed by the First Congress of the Chairs of Public Business Law. ${ }^{11}$ It is understandable, however, that the constant development of this branch of law, encompassing the ever-expanding range of matters subject to legal regulation, also poses new challenges, especially to legal science.

Nowadays, it is paradoxical that (apparently) contradictory aspirations exist, and yet at the same time there is need to make proper connections between them. Thus, the postulate assigned to law since the systemic transformation has been deregulation, ${ }^{12}$ and the economy is increasingly subject to economic principles. On the other hand, it is obligation of the state to introduce new laws and control their implementation in the name of the common good. At the same time, it is also expected that the interests of individuals be protected, and these may be at odds with the interests of the collective. Therefore, it is necessary to enact new regulations and special forms of action for their protection. It follows from this that recourse to general guarantees of individual human rights may prove insufficient in the economic world. ${ }^{13}$

Another contemporary challenge is achieving harmonization with European Community law. Along with the changes in the legal system caused by fundamental systemic restructuring (the domestic legal system) the influence of Community law is growing, and the Community governs itself, to a certain extent, with its own rules. The bodies of the

10 For several general remarks on this subject see: T. Rabska, Rozwój nauczania publicznego prawa gospodarczego - przyczynek do dyskusji, PUG 2005, No. 9, p. 2 ff.

11 Zjazd Katedr Prawa Gospodarczego Publicznego - Konferencja nt. "Instrumentów i form prawnych działania administracji gospodarczej”. Gniezno 20-22 September 2007, see the report in RPrEiS 2007, facsim. 4, pp. 194-196.

12 "Deregulation" - understood as a direction aimed generally at limiting legal regulations in the economy, i.e. is aimed both at repealing legal provisions that hinder the operation of economic laws, or which are incompatible with them, and at counteracting the emergence of new legal acts of this type that hinder business operations.

13 See the statement of M. Safjan: "The constitutional principle of economic freedom [...] does not completely fit in the area of the principle of individual freedom [...]. The principles of both these principles intersect" - and later: "constitutional guarantees of individual freedom do not translate in a direct or necessary way into a specific economic model” in: System prawa cywilnego. Zasady prawa prywatnego, p. 275. 
State, which is a member of the economic community, are obliged to implement this law. Community law, which in its broadest scope refers to the economy, thus exerts the strongest influence precisely on business law, on the application of this law and the control of its observance.

The study of business law is therefore at a crucial turning point. The wide range and diversity, as well as the high degree of difficulty associated with new problems that are constantly arising, have a fundamental influence on the constant development of the discipline, its subject matter and scope of research. Its task cannot only be to resolve current dogmatic-legal problems, which in itself-in the face of dynamically emerging changes_-constitutes an important challenge: legal science must go beyond the description and analysis of applicable law in particular fields of the economy, and address theoretical issues associated with new legal phenomena. ${ }^{14}$

A special role in determining the institution of public business law and the so-called general parts, addressing the basic issues of this discipline, is played by textbooks that cover the whole issue of this law in a general manner. ${ }^{15}$

A valuable contribution is made by (monothematic) collective scientific works that focus on selected problems and legal institutions specific to this branch of law. It is worth mentioning books on the function of contemporary economic administration ${ }^{16}$ and legal measures of public business law ${ }^{17}$. This role is also fulfilled by the present collective work

14 On the issue of particular legal sciences (the science of particular branches of law) and their tasks v. Z. Ziembiński, Szkice z metodologii szczegółowych nauk prawnych, WarszawaPoznań 1983, p. 7 ff.

15 In effect, each university center has a textbook based on its own concept of the discipline. The differences are due to the degree that Community law has been introduced. For example, the textbook of C. Kosikowski already announces in its title "Public Business law of Poland and the European Union”. C. Kosikowski, Publiczne prawo gospodarcze Polski i Unii Europejskiej, Warszawa 2005. However, differences in the titles of textbooks, such as choosing "administrative" rather than "public business law", does not entail fundamental changes concerning their thematic scope.

16 Funkcje współczesnej administracji gospodarczej, ed. B. Popowska, Poznań 2006.

17 Środki prawne publicznego prawa gospodarczego, ed. L. Kieres, Wrocław 2007. 
devoted to the instruments and legal forms of the activities of economic administration, which is the result of the debate of the Congress of the Chairs of Public Business Law mentioned above.

Taking into account the extent of the rich literature of this discipline, the monographic works that shape the multi-segment system of public business law ${ }^{18}$, it can be safely assumed that there are already grounds for building a system of public business law.

\section{The Assumptions and Goals of Public-Law Regulation of the Market Economy System}

It is necessary to define a new perspective on the role of public business law, and the place of public-law norms in the economy, which essentially runs on economic rules. The goals of legal regulations change along with the growing transformations in economic relations. In contemporary terms, this entails a total rejection of the concept of business law as the law of "managing the economy". This is because the State has ceased to be an economic entity — an entity engaged in an economic activity. The continued existence of state enterprises or the one-person company of the State Treasury does not undermine this thesis, although the legal position of these units in the economy is undoubtedly specific. The constitutional foundations of the economic system have fundamentally changed relations in this sphere. In its public activity, the State cannot legitimize itself by entitlements derived from its own means of production ${ }^{19}$, neither is it the addressee of constitutional freedoms and economic rights-it rather became their guarantor. ${ }^{20}$

18 It is not possible here, even as an example, to enumerate all the positions outlined in the literature of the subject. This would require a separate study that would cover both books and scientific articles addressing a broad spectrum of economic problems.

19 In Prawny mechanizm kierowania gospodarka, Wrocław-Warszawa-Kraków 1990pp. 11-69, completed in 1987. Characterizing the critical stage of the past economic system, I indicated the determinants of the State's position in the economy, namely: the ownership of the means of production, managing the economy on the basis of the central planning, and the introduction of a centralized organisational structure of the state economy adjusted to these factors.

20 V. in particular: Chapter II of the Constitution, Article 64, Chapter I of the Constitution, and Articles 20-21. 
The fundamental breakthrough in these relations, as I have already emphasized, took place in 1989. However, this did not entail an automatic one-off derogation of all the then-existing legal provisions. Since it is accepted that there must be a certain degree of continuity in the legal system, ${ }^{21}$ only subsequent amendments and the introduction of new legal acts made it possible to gradually build appropriate legal structures that could serve to resolve problems associated with the appearance of new phenomena in the functioning of the economy. The obligation to bring Polish legislation closer to Community legislation (Article 68 of the European Treaty), and then the obligation to "implement" Community law (Article 2 of the Accession Act) set new goals and directions for further transformations.

Without going into the successive reconstruction of the legal bases, it must be assumed that, first and foremost, the assumptions and objectives of applying the rules of public business law in economic regulation had to be changed. ${ }^{22}$ In a market economy system, the purpose of these rules is not to 'regulate' all the actions of economic entities. Neither is their objective to guide economic processes. However, it is significant that after the rejection of the State-run economy and with the abandonment of direct economic management by the central party apparatus, the proper role of business law returns - a role completely different to the previous one. What is more, its significance grows with the continual emergence of new economic phenomena.

The causes of such a state of affairs should be sought in the new systemic conditions - with the adoption of the division of the public and private economic spheres - there is an urgent need for a clear legal determination of the tasks of the State and the scope of its necessary interference in economic relations (which is justified in certain situations), and on the other hand, the legal situation of entities engaged in economic activity (also under public-law) and the protection of their

21 On this subject inter alia: T. Rabska, The Transit from a Centrally Planned Economy to a Market System, in: Public Administration in the Nineties: T-ends and Innovations, Wienna 1992.

22 For very convincing remarks on this subject v. M. Safjan, op.cit., p. 44. 
position and economic rights. ${ }^{23}$ This area of public legal protection also requires the individual be treated as a "consumer". ${ }^{24}$ Due to Poland's membership in the European Union, new state obligations arise, both with regard to the Community's organs, as well as the need to shape internal relations accordingly. Thus, it is the State apparatus and its tasks that are subject to a wide range of legal regulations ${ }^{25}$ and, consequently, the control of their implementation.

All these factors shape the basic assumptions of public business law, both with regard to the material of regulation and the subjective scope. The needs of the modern system of regulation involve the necessity of determining legal relations on different levels, in various relations and mutual interconnections. In addition to the typical relations in vertical arrangements, between the State organs and the individual (which are still very important), there are also links between individual State bodies involved in general economic problems, with legal provisions allocating various tasks between these bodies and social (civic) partners, as well as the cooperation in this respect with Community organs. ${ }^{26}$ The aim of legal provisions is therefore to achieve full coordination of actions taken, to ensure their clarity and, above all,

23 L. Kieres conceives this differently in the book Administracyjne prawo gospodarcze, Wrocław 2005, p. 23.

24 Just as an example one can refer to the appointment of such institutions as the "consumer ombudsman". V. the Scope of activity and tasks of the county Article 4.1, item 18 of the Act on County Self-Government)

25 On the extensive functions of the State in the economy, see: Funkcje współczesnej administracji gospodarczej, in particular: B. Popowska, Klasyfikacja funkcji administracji w nauce publicznego prawa gospodarczego, p.61 ff., also K. Kiczek, Funkcje administracji gospodarczej jako przedmiot badań, p. 39 ff.

26 When analysing "systemic administrative business law” K. Strzyczkowski writes inter alia: "The advantages of separating the systemic administrative business law are increased by the effects of European integration based on the Europeanisation of administration structures [...]. Of key importance is cooperation between Community bodies and the administration of the Member States (vertical relations), and between administrative bodies of the Member States (horizontal relations)" in: K. Strzyczkowski, Prawo gospodarcze publiczne, Warszawa 2007, p. 43. For more detailed discussion v. I. Lipowicz, Europeizacja administracji publicznej, "Ruch Prawniczy, Ekonomiczny i Socjologiczny” 2008, p. 5. 
to ensure the responsibility of the State for the common good, defining the space of activity of its organs. ${ }^{27}$

The delineation of the general principles of public-law regulation also determines its place in the entire legal system with reference to the modern economy, as well as relations in this area with other legal disciplines. The aim of public business law is not to "appropriate" economic relations at the expense of other regulations, nor replace them. It is therefore necessary to correct the still erroneous views of a special kind of competition between ways of shaping economic relations, in particular between public and private regulations. Thus, it has to be emphasized that establishing public-law norms may also aim at both guaranteeing legitimate economic rights and the proper implementation of other types of legal relations. ${ }^{28}$ The complexity of various economic phenomena and the need for their multi-level solutions emphasize even more strongly — from the theoretical point of view - the aims and functions of public business law, its place in the legal system and necessary connections with other regulations.

A separate issue that lies beyond the scope of this study, concerning rather the sphere of law-making, is the question of whether and to what extent applicable legal provisions implement this model of regulating economic relations and ensure the coherence of internal and proportion between various regulations.

Considering public business law, and in particular its objectives and the complexity of its subject matter, the problem of the methods of application and interpretation become fundamental, and above all, the type and legal character of activities undertaken by the State authorities.

27 V. A. Chełmoński, Realizacja dobra publicznego a ochrona interesów jednostki, in: Administracyjne prawo gospodarcze. Zagadnienia wybrane, ed. A. Borkowski, A. Chełmoński, M. Guziński, K. Kiczka, L. Kieres, T. Kocowski, Wrocław 2000, p. 65.

28 When providing a broad analysis of the "publicizing of private law", M. Sajfan describes the current situation very fittingly: "the encroachment of proprietary methods [...] is a kind of support in relation to these (private law) solutions (it is complementary to them), and is not directed towards the elimination of the private-law method as such and its replacement by public-private regulation”, p. 49. 
The conference of the Congress of the Chairs of Public Business Law and the works published in this volume are devoted to this fundamental issue.

\section{Determinants of the Correctness and Effectiveness of Public Business Law}

The attempts made in legal science to assess the correctness of legal solutions generally refers to a selected legal act, or group of legal provisions, and focuses on a specific issue that is subject to a given regulation of public law. In this context, the correctness of legislation is analyzed, and the provisions that are supposed to contribute to achieving a specific objective are assessed. On the other hand, these issues are rarely considered in relation to the system of public business law as a whole, and in relation to the object of this law, which is the economy. ${ }^{29}$ This is due to the fact that individual segments (subsystems) of public business law concern various areas of the economy and serve various interests (collective, group, individual), or focus on only specific entities (be it entrepreneurs, groups of entrepreneurs, consumers, or only on public administration bodies), or they concern specific business activities, etc. The criteria for assessing these individual legal acts and their effectiveness may, therefore, vary from case to case.

Another issue is that public business law, which is a component of a uniform legal system, as well as individual legal acts included in this branch of law, are subject to evaluation from the point of view of the principles which are generally applicable for the whole legal system, both constitutional and doctrinal. These principles will not be analyzed here. ${ }^{30}$ On the other hand, the entity indicated above, which is subject to

29 On the criteria for differentiating the legal system and its consequences, see in particular Z. Ziembinski, pp. $114 \mathrm{ff}$.

30 However, it should be noted that some of the general principles are ascribed special importance as principles of public business law, v. K. Strzyczkowski, Zasada państwa 
legal regulation — $\mathrm{n}$ this case, the economy ${ }^{31}$ — tends to make particular demands of business law. ${ }^{32}$ It is necessary to refer to the scope of lawmaking activity, the activity of public bodies and the legal position of the individual - entrepreneurs. These factors necessarily have an influence on legal regulations. Consequently, they should be reflected in the process of law-making, in the substantive content of legal acts, and they should also influence the interpretation of law and the methods for its application.

In my view, the following should be included among the particular deteminants:

1) the necessity of linking normative content with the requirements of business law, derived from essence of commerce (in the broad sense of the term).

2) taking into account the principle of subsidiarity in determining the limits of state interference in economic relations,

3) basing public business administration on the principle of decentralization, leading to the selection of the competence and responsibility appropriate for the case.

These factors seem to be of diverse nature, defining the various levels of events. However, in shaping activities and legal relations they complement each other. The degree to which they are considered may have a significant impact on the mechanism of the functioning of public ad-

sprawiedliwości społecznej jako zasada publicznego prawa gospodarczego, "Ruch Prawniczy, Ekonomiczny i Socjologiczny” 2007, p. 11.

31 The concept of "economy" is employed in a broad sense here, with all its determinants. It is not possible to clearly define the boundaries of "economy" in advance, as the legal reference framework for legal regulations. For different ways of defining the economy, v. K. Strzyczkowski, Gospodarka jako przedmiot regulacji prawnej, in: Prawo gospodarcze publiczne, Warszawa 2003, p. 23.

32 A. Chełmoński, Swoiste zasady administracyjnego prawa gospodarczego, in: Administracyjne prawo gospodarcze, ed. L. Kieres, Wrocław 2005, p. 61. In particular, the principle of "protecting the proper functioning of a market economy" should be emphasized (p. 62), and the "principle of the protection of interests" (p. 64). However, they primarily define the objectives behind law-making. In another conception of "principles of public business law" are presented by K. Strzyczkowski, op. cit., pp. 49-98; v. T. Rabska, Gospodarka rynkowa i jej zasady, Warszawa 1995. 
ministration bodies and the activities undertaken by them, depending on the specific circumstances, in forms (legal and factual) adequate to the given situation. These are therefore requirements for the correct application of the law.

1. The question of taking economic principles into account in legal regulations is complicated both doctrinally (the issue of two separate sciences) and from the legislative point of view (various methods of expression). In the simplest terms, it concerns the boundaries between market mechanisms and legal norms; above all, what issues (and matters) should be subject to legal regulation at all, and then the scope of legal regulations that regulate or limit the operation of economic laws, the degree to which legal provisions interfere. These issues are additionally influenced by a whole range of non-legal factors, primarily economic policies and the social situation.

The issue of linking law with economics is addressed in the literature in many respects, such as in the "economic analysis of law". ${ }^{33} \mathrm{Re}-$ garding the content of the provisions of business law-from a juridical viewpoint-it is essential to ultimately and properly link the necessary economic requirements (at various scales) with the content of legal regulations. In the case of public business law, it is primarily to guarantee the effectiveness of the functioning of the economy as a whole, in line with the public interest.

The requirements should therefore be implemented in the course of law-making, in its successive stages_-drafting legal acts, seeking and expressing opinions, consultations ("cooperation between social partners”) and passing legal acts. ${ }^{34}$ Lack of due diligence (or even negli-

33 On this topic, see the review article of R. Tokarczyk, Jednostronność ekonomicznej analizy prawa, "Ruch Prawniczy, Ekonomiczny i Socjologiczny” 2007, p. 175 and the literature cited therein. J. Stelmach, B. Brożek, W. Załuski, Dziesięć wykładów o ekonomii prawa, Warszawa 2007.

34 This is how K. Strzyczkowski understood the issue, arguing that "economic analysis should [...] precede the intention to subject a specific field of (economic) life to legal regulation"; K. Strzyczkowski, Prawo gospodarcze publiczne, Warszawa 2011, p. $31 \mathrm{ff}$. 
gence) at this stage may be the cause of many distortions and contradictions between the actual state of affairs and the legal regulations.

Because various views are expressed, it should be clearly emphasized that when referring to economic requirements the point is not to encourage "economic efficiency", in the sense of maximizing wealth as the "sole purpose of law". ${ }^{35}$

For the implementation of these assumptions-it must be stressed once again - the stage of the law-making process is of fundamental importance. At the same time, it is important that, despite the multiplicity of legal acts regulating the economy, coherence between them is maintained, so that their goals - from the point of view of the assumptions behind them — do not conflict with each other, or are not mutually exclusive, but are rather complementary to each other.

Only such a procedure for enacting legal acts can ensure the coherence and transparency of provisions and shape a unified legal system. As part of the system, it is necessary to use a uniform conceptual apparatus which will give a uniform legal sense to the constructions adopted. ${ }^{36}$ Otherwise the process of their uniform interpretation and application will be very difficult.

In passing, it should be mentioned that the introduction of the concepts and terminology of Community law is a new element that is not simple to apply. Community laws do not always coincide with wellknown national laws and the constructions employed in domestic legal science. However, this is a separate issue and requires the investigations of scientific analyses. ${ }^{37}$

2. Although it is more difficult to apply the principle of subsidiarity to all legal situations to the same degree, it seems justified that it

35 See the critique of this position: R. Tokarczyk, op. cit., pp. 176-177.

36 The details of the legislator's the misuse of the term 'nadzór' (control, supervision), and the lack of appropriate legal content and means of action associated with it, should only be used as an example.

37 For example R. Blicharz addresses the problem of European regulation of the criteria for supervision of the capital market. 
should find proper application in business law. It should be taken into account in the law-making process and fully respected in the application of law. It should be attributed the status of a legal principle, because it is referred to in the Polish Constitution, as well as the Treaty establishing the European Community and the European Charter of Local Self-Government. ${ }^{38}$

Its meaning derives from the fact that the State and its organs are to serve the citizens. Therefore, the law should not interfere in those relations and those activities which, due to their nature, may exist without legal interference, without the unnecessary actions of public bodies undertaken independently by interested parties. However, in situations in which, for the fulfilment of certain objectives and when public interest requires it, legal regulation is necessary, it would be essential to seek to ensure that legal actions-depending on the issues_-be taken "as close as possible to the citizen", and thus at the lowest levels of the power structure. ${ }^{39}$

The observance of these requirements guarantees not only the rational behaviour of interested entities (public and private), but also creates the conditions for developing initiatives and provides closer insight into a specific market. ${ }^{40}$

38 The principle of subsidiarity is expressed in the preamble of the Constitution of the Republic of Poland, which refers to "strengthening the powers of citizens and their communities". With regard to the actions of public authorities, "a self-governing community" is referred to; Article 16, Article 163 of the Constitution of the Republic of Poland. With regard to the European Union, see Article 5 TEU and Article 4, sec. 3 of the European Charter of Local Self-Government.

39 This is clearly expressed in the European Charter of Local Self-Government: "Public responsibilities shall generally be exercised, in preference, by those authorities which are closest to the citizen. Allocation of responsibility to another authority should weigh up the extent and nature of the task and requirements of efficiency and economy" (Article 4 point 3).

40 On the subject of subsidiarity: W. Łaczkowski, Ekonomiczne i socjalne prawa człowieka a dobro wspólne, Warszawa 2003, p. 6; L. Bar, Publiczna subsydiarna działalność w gospodarce rynkowej. Wybrane zagadnienie prawne, "Państwo i Prawo" 1994, no. 6; A. Szpor, Państwo a subsydiarnośc jako zasada prawa w UE i w Polsce, "Samorząd Terytorialny" 2001, no. 1-2, p. 3 ff. 
3. The provisions of public business law are addressed in a broad scope to public administration authorities-economic administration entrusted with the execution of various types of public function. This is related to determining the scope of public tasks and proper competences to undertake actions. Thus, the exercise of public authority in the economic sphere requires a choice between appropriate organizational structures for the tasks (organs, agencies etc.), as well as appropriate methods of action for these entities, and the relations between the participants of these activities.

The matter of the proper organization of the State apparatus in the context of exercising economic functions is quite rarely considered in the literature. ${ }^{41}$ Yet this is an important issue, taking into account the specific economic system. The organization of the administration should be determined by the tasks, not vice versa. Unreformed structural solutions can be incompatible with a given system; they may inhibit its proper functioning. For example, a centralized system of public administration is contrary to a system based on the principle of freedom of economic activity. It can lead to actual interference through the concentration of power in one center. Delegating all public tasks and competences, and their concentration only at high levels of public authority (and without them thereby being burdened with responsibility), does not provide any guarantee that the governing policy will not have an effect on the functioning of the economy.

41 The need to properly adapt organizational structures to the requirements of the market economy was addressed at the beginning of the systemic transformation. V. Wstępne założenia przebudowy administracji publicznej, Warszawa 1992, p. 19: "VIII. Warning forecast. The system of public administration functioning so far in itself has constituted an obstacle to implementing necessary reforms of the economy and the State. The urgent decision concerning the direction of reform of the public administration, and the principles of their introduction therefore determines the further implementation of the transformation policy and its success”. I addressed this issue in the article Zasada gospodarki rynkowej a samodzielność jednostek samorzqdu terytorialnego, in: Ex iniuria non oritur ius, Poznań 2003, p. 91 ff. On the subject of the company's links with the region see: A. Szronnik, Przedsiębiorstwo a region - relacje i współzależności rynkowe. "Samorząd Terytorialny” 2008, no. 7-8, p. 101 ff. 
For the above reasons, it is appropriate to enact decentralizing arrangements in legal provisions, concerning individual sectors of the economy. They ensure that individual entities at the local levels of management have-depending on the type of issue - the necessary independence in performing their functions. ${ }^{42}$ The rationality of actions and their effective undertaking requires a coherent conception of institutional solutions and, when necessary, of the whole economic apparatus.

The extent to which these particular requirements are considered in the content of provisions will undoubtedly have an effect on the level of applying the law and the direction of its interpretation. This should be conducive to the uniformity of interpretation. It would also have great significance for the multiplicity of legal subsystems, with regard to various segments of the economy ${ }^{43}$.

In passing, an important legislative issue is worth mentioning at this point, namely the lack of codified regulations in this area, including the comprehensive and exhaustive sphere of legal relations. ${ }^{44}$ Therefore, determining some general rules is an even more urgent task of legal science. $^{45}$

42 The scope of activity of the voivodship self-government includes, inter alia, "raising the level of the competitiveness and innovativeness of the voivodship's economy". Act of June 5, 1998, On Voivodship Self-government, Article 11. Without assuring the autonomy of the voivodship authorities in the legal provisions concerning various sectors of the economy, this statutory provision cannot be fully implemented.

43 The oft-referred to separation of particular areas of business law is reflected in how the content of academic textbooks and in numerous monographic works is organised.

44 There is no "Code of Public Business Law" or a code covering economic issues of private law. This is to a large extent a problem of legal theory, resulting from the tendency to maintain the basic unity of legal systems. With regard to private law issues. V. M. Safjan, Status prawa gospodarczego, in: System prawa cywilnego, op.cit., p. $57 \mathrm{ff}$.

45 Z. Ziembiński, Problematyka dogmatyczna nauk prawnych - rdzeń nauk szczegółowych, in: Szkice z metodologii szczegółowych nauk prawnych, Warszawa 1983, p. 10 ff. 


\section{The General Characteristics of Public Administration Activities in the Economic Sphere}

One of the most important issues of the application of public business law is the right selection, broadly speaking, of the "instruments of action" made by the organs of public administration (and other public entities), upon which this law imposes certain tasks. ${ }^{46}$ For the sake of simplicity, this group of public entities can be defined as pertaining to "economic administration", indicating both the subject and object of interest. It is an issue that is still current, considering the continuing development of economic relations and public business law.

Nowadays, the issues are so extensive that it is difficult to find an adequate concept covering all of these activities which would emphasize their legal nature. Various terms have been adopted, e.g.: "the legal means of public business law", 47 "the means and legal forms of economic administration bodies", 48 "the legal forms of economic administration activity"49 and, maybe the most encompassing, "the instruments and le-

46 The issue of legal instruments and the actual actions of public administration bodies is constantly valid at all stages of the development of public business law (previously administrative law of economic relations). Just by way of example, reference can be made to the first words of the Introduction to Formy prawne oddziaływania naczelnych organów zarzq̨dzania gospodarkq narodowq na organizacje gospodarcze (Warszawa 1974). The results of research conducted by INP PAN under the direction of L. Bar and T. Rabska: "One of the most important problems associated with the contemporary system of management is the appropriate selection of instruments for management, i.e. the issue of how to manage, by what means, and in what forms" It should be mentioned that in 1974, due to the prevailing economic system, analysis of actions referred to management.

47 This is the title of the collective work: Środki Prawne Publicznego Prawa Gospodarczego, with an Introduction by L. Kieres: "the contemporary administration and its organs find a legal approach to relations with entities which associate their status with its activity".

48 K. Strzyczkowski, Środki i formy prawne organów administracji gospodarczej, in: Prawo gospodarcze publiczne, Warszawa 2011, s. 179, begins with these words: “The effectiveness of functions of public authorities (administrations) realized in the economic sphere, to a large extent depends on the use of appropriate legal measures and legal forms of operation”.

49 K. Pawłowicz, Prawne formy działania administracji gospodarczej - kierunki zmian i próba oceny, in: Instrumenty i formy prawne działania administracji gospodarczej, eds B. Popowska, K. Kokocińska, Poznań 2009. 
gal forms of the activity of economic administration". ${ }^{50}$ The latter term is so broad that-one may conclude-it concerns not only legal acts aimed at directly realizing legal effects, but also of another type of action. It is also possible to talk generally about "the legal mechanism of administration”, in particular by including the legislative and planningstrategic activity of public authorities. ${ }^{51}$

In view of the factual diversity of "institutions", "forms" and "measures", it seems advisable to accept a broader scope of the concept of "the activity of economic administration". ${ }^{2}$ In general, the point is to adapt the activities of public authorities, on the one hand, to the manner and scope of necessary State interference in economic relations, and, on the other hand, to match activity to the properties of these relations and the actual demands of the market's functioning.

These actions (legal and factual acts), and their character, result from the essence of public business law-its function in the economic system. The provisions of this law determine the public-law nature of the actions taken, and the object of the law-the economy-shapes their content. Therefore, they are aimed primarily at the implementation of State tasks by empowering individual bodies to undertake different activities and determine their form. These provisions are generally provisions of the type iuris cogentis. Their legal effect is usually the obligation to take action.

The law also places special measures of an economic type at the disposal of the organs - means of material support, at the same time establishing the procedures and ways of applying them. ${ }^{53}$

50 This is the title of the collective work Instrumenty i formy prawne działania administracji gospodarczej, eds. B. Popowska, K. Kokocińska, Poznań 2009.

51 T. Rabska, Prawny mechanizm kierowania gospodarkq, in relation to the activities of public administration bodies.

52 The proposal to develop a broader scope of the concept of "administrative action" was put forward by F. Longchamps in 1965. F. Longchamps, Węzłowe problemy podstawowych pojęć prawa administracyjnego, "Państwo i Prawo" 1966, p. 895. From this it is evident how important the diverse activities of the administration were for legal science.

53 K. Strzyczkowski writes about "financial incentives” in: Prawo Gospodarcze Publiczne, p. 182. In the collection Instrumenty i formy prawne działania administracji gospodarczej, 
In general, therefore, in terms of public business law, taking into account its general conception, one can in some sense talk about the legal shaping of economic relations (in various sectors of the economy, to varying degrees), the content and scope of which should correspond to the contemporary conditions of market functioning and public interest, while at the same time protecting the sphere of properly understood individual interests. ${ }^{54}$

Economic relations, which are increasingly complex and change under the influence of various factors, entail the necessity to look for the effective actions which are most adequate to these relations and general political assumptions. For this reason, the traditional public-law forms that create the basic catalogue of administrative-legal activities - the appeal to which was, in principle, the rule in the initial period-become insufficient. Public business law starts to become a set of specific activities, which are different in its various segments (subsystems). The striving to establish the legal character of activities in relation to particular functions performed, concrete tasks limited to specific sectors of the economy etc. becomes characteristic. ${ }^{55}$ If attempts at general characterization and classification are made, they generally do not cover the entirety of administrative activities. ${ }^{56}$

eds B. Popowska, K. Kokocińska, Poznań 2009 on the subject of various forms of granting public aid v. B. Popowska.

54 A very deep analysis of the conditions for implementing economic freedom and the principle of autonomy of the will, which find expression in the principle of contractual freedom, can be found in: M. Safjan, System Prawa Prywatnego, Chapter VI Zasady prawa prywatnego, section 25.1 Zasada autonomii woli, p. $273 \mathrm{ff}$.

55 This is fully reflected in the collection Instrumenty i formy prawne działania administracji gospodarczej, eds B. Popowska, K. Kokocińska, Poznań 2009, as well as in textbooks of public business law and in monographic studies.

56 V. the collective work: Publiczne prawo gospodarcze - Zagadnienia ustrojowe, materialnoprawne i proceduralne Struktura wykładu i materialy źródlowe, ed. B. Popowska, Poznań 2006, in particular the chapter Formy i metody dzialania organów administracji publicznej w sprawach gospodarczych, p. 24 and p. $90 \mathrm{ff}$. 
One cannot overlook the fact that the organs of public administration are permitted to undertake actions in a private-law mode- - bilateral acts, based on the parity of parties. In addition to administrative (public-law) contracts, as a new, developing form of action, they are subject to the rules of civil law. The provisions of public business law may, however, introduce specific restrictions or special requirements precisely due to the fact that these activities are undertaken by a public entity-with a purpose determined in advance-for the performance of specific tasks. Due to differences, some of these activities may take on a specific form.

It is becoming increasingly difficult, due to the variety of issues to be regulated and the very different (and imprecise) way of determining the authorities' competences to take action, to establish their comprehensive catalogue and-on the basis of a uniform criteria-introduce a transparent classification. This is not facilitated by legal provisions, due to the lack of uniform conceptual apparatus concerning the forms of activity. In addition, some legal acts contain the content of private and public law norms, with various relations between them. The state of law in this area-the multiplicity of legal acts, the lack of coordination between them, and the endless revisions - should be assessed critically.

It is necessary to add that the basic element which decides on the correctness and effectiveness of actions concerns the procedures for their undertaking and the mode for controlling them-instance and court. In view of the fact that the legal route (generally ordinary courts instead of the administrative courts) is not always adequate to the nature of the proceedings, the criterion for explicitly defining the legal character of some forms of activity is blurred. This would require the development of new concepts and proper determination of the limits of court cognition.

The comprehensive organization of the very important sphere of public business law is a serious challenge for the study of this law. The 
undertaken analyses and scholarly works, including those in this collection, lead to the establishment of specific legal forms in this field, appropriate for this type of law. Both individual and general forms taken in economic matters - generally speaking — in the public-law mode, are characterized by particular features. Although with many of them it is possible to refer to features typical of administrative acts (decisions), acts of administrative law or (as in the case of public-law contracts) features of civil law contracts, they are always based on specific legal grounds that provide them with additional requirements.

Therefore, the fundamental assertion is that there are separate forms of action proper to public business law. The variety of activities, their forms and diverse methods of operation entail a number of further consequences.

One can, of course, discuss whether the multiplication of different types of legal forms is appropriate, and also from the point of view of the systematics of law, the clarity and uniformity of rules for the application of the law, and the protection of the rights of the individual subject. At the present stage, however, this has been determined by the rapid development of social relations, new forms of business-which completely disrupted the traditional framework. This was also helped by the introduction of the regulations of Community law into the domestic order. An unavoidable consequence of these phenomena was also the establishment of new tasks of State organs, new relations between organs (also Community organs), and above all between them and business entities, and in relations between these entities and consumers. This exerts an impact on all areas of law, including the multiplication of various categories of contractual relations that exceed the limits of the Civil Code. This disturbance in the system is not unique to public business law.

It required rather fundamental transformation of the relations of the authorities to new phenomena. The appearance of new types of activities found expression in legal provisions. Thus, the need arose to establish their legal classification and criteria for division. Traditional divisions, 
despite the continuation of traditional forms of action, no longer fulfill their role adequately.

In general, the centre of gravity of activities has shifted from individual acts of power, which decide on the possibility of individuals undertaking economic activities, to actions and general acts (legal and factual), preferring directions of activity (information, strategies, directions of development policy). Such tendencies are indicated by studies published in this collection. ${ }^{57}$ This is in line with the general conception of public business law. As far as individual acts (decisions) are concerned, they are far from typical forms. ${ }^{58}$

In no way does this entail the diminished importance of individual administrative acts (decisions) shaping the legal situation of individuals and having - in individual cases - an impact on the actual scope of the principle of freedom of economic activity ${ }^{59}$ On the other hand, in these forms, public administration organs issue prescriptions to forbear certain activities or prohibitions of certain behavior. ${ }^{60}$ They can also find application in the process of proprietary transformations, such as commercialization. ${ }^{61}$

However, the activities of public administration organs that are particularly characteristic for this area are those specifically aimed at supporting economic development, creating conditions for running a business, and ensuring the efficient functioning of the market. They result from specific duties of these organs, stipulated in legal provisions. ${ }^{62}$

57 V. the collection edited by A. Walaszek-Pyzioł, K. Kokocińska, M. Będkowski-Kozioł.

58 V. inter alia: L. Kieres et al., Instrumenty administracyjnoprawne $w$ systemie oceny zgodności z zasadniczymi wymaganiami, Wrocław 2009.

59 In addition to typical legal forms, such as concessions, permits, permits, there are also specific types of decisions; see K. Kiczka, Administracyjne akty kwalifikujq̨ce w działalności gospodarczej, Wrocław 2006.

60 For example, prescriptions in the case of applying restrictive practices or prohibitions on acting in concert; see: C. Banasiński, Publicznoprawne aspekty ochrony konkurencji, in: Prawo gospodarcze. Zagadnienia administracyjnopraune, Warszawa 2007, p. 270.

61 V. A. Trela, Nowe formy działania ministra właściwego do spraw Skarbu Państwa w procesie komercjalizacji i prywatyzacji, in: Instrumenty i formy prawne działania administracji gospodarczej, eds B. Popowska, K. Kokocińska, Poznań 2009

62 The problem of state obligations in the economic sphere is addressed in the literature, for example K. Kiczka writes: "the involvement of the State in the economy of [...] must be 
This group of acts is on the increase. Legal provisions introduce new forms, giving them new names and content, and — significantly — they stipulate specific procedural requirements. ${ }^{63}$

The relationships emerging between different categories of legal acts and formalized factual relationships (to a greater degree factual than formal-legal) make up this very extensive system of public authority activity. Lack of consistency between them may have a negative impact on the functioning of the economy, its individual sectors, and hinder the implementation of individual rights in this area.

The general characteristics of the legal forms of economic administration require that attention be paid to one more of their specific characteristics associated with the application of the law-the development of particular types of legal forms will remain under the influence of specific methods of action, appropriate to public business law and corresponding to its fundamental assumptions. It is very characteristic for this sphere of relations and influences the way the administration operates in this area. It especially concerns the continual introduction of new acts of law application.

For example, a great deal of significance is attributed in economics to a method that can be conventionally described as a "method of regulation" and, which may be surprising from the theoretical point of view, "regulation" is actually not a concept with strictly defined legal content. ${ }^{64}$ It serves first and foremost, however, to highlight the change (or modification) in the methods by which state authorities execute their tasks, and their impact on selected sectors of the economy. This where its cog-

considered [...] in terms of a legal obligation and the resulting legal liability of the public authority for acts or omissions in that field of social relations."

63 For example, legal provisions often impose an obligation for economic administration bodies to take legal acts or actions in cooperation with other public entities, as well as, for example, in consultation with business entities or other entities.

64 A detailed analysis of the concept of "regulation" is provided by T. Skoczny, Stan i tendencje rozwojowe prawa administracji regulacyjnej w szczególności, in: Ius Publicum Europeum, Warszawa 2003, pp. 115 ff, Warszawa 2008, especially p. 148 ff. T. Kocowski, Reglamentacja a regulacja, in: Administracyjne prawo gospodarcze, p. 504 ff.; Regulacja rynku telekomunikacyjnego, eds M. Kulesza, A. Szpor, Warszawa 2005. 
nitive significance lies. ${ }^{65}$ As a consequence, even in the State structure, "regulatory authorities" are appointed to carry out specific special tasks. Their implementation thus serves a properly selected form of action. ${ }^{66}$ From a formal point of view, this does not necessarily mean a total rejection or change of the legal forms that have existed in the system thus far. The issue really concerns the purpose of the activity and its adaptation to specific needs. Full reflection is found in the performance of State responsibilities in the broadly understood sphere of public utility.

A separate issue is the characterization of the legal basis (sources of law) of the undertaken forms of activity of economic administration. Of particular importance, particularly in the field of economic relations, is the application of the principles of Community law, both in particular legal acts (primary and secondary law), and in the extensive jurisprudence of the European Court of Justice. This leads to consequences for the adoption of domestic legal acts. This, however, falls beyond the scope of issues discussed here.

To sum up, the development of public business law has led to the formation of its own network of legal forms of public administration activity. On the other hand, it is the specific nature of these measures that determines the separation and essence of public business law. These separations are indicated by the significant breakthrough in the dogmatic and doctrinal framework of this branch of law. With this borne in mind, it does not seem justified to identify its genesis as lying in administrative-law. ${ }^{67}$ Nevertheless,

65 In passing, it should be mentioned that the concept of "regulation" is not the opposite of "deregulation."

66 V.P. Lissoń, Formy oraz instrumenty prawne działania organu regulacyjnego na przykładzie Prezesa Urzędu Regulacji Energetyki Instrumenty i formy prawne działania administracji gospodarczej, eds B. Popowska, K. Kokocińska, Poznań 2009.

67 V. the current names of textbooks: Administracyjne prawo gospodarcze, Wrocław 2005; Prawo gospodarcze. Zagadnienia administracyjnoprawne, Warszawa 2007; v. J. Boć, W sprawie zakresu administracyjnego prawa gospodarczego, in: Prawo administracyjne, ed. J. Boć, Wrocław 2007, p. 49; K. Kiczka, Prawo administracyjne gospodarcze w systemie prawa administracyjnego, in: Koncepcja systemu prawa administracyjnego, ed. J. Zimmermann, Warszawa, 2007, p. $67 \mathrm{ff}$. While fully respecting the various concepts used for grasping economic issues, I do not think it is advisable to equate the following names and use them interchangeably: "administracyjne prawo gospodarcze” (administrative business 
emphasizing the public character of this law ${ }^{68}$ does not entail breaking the links between administrative law and public business law, either in terms of the theoretical foundations and positive sources of law. Similarly, there are close links between public and private business law. This also constitutes the specific nature of public business law and the methods of its application.

In the study of public business law a wide range of research is undertaken into particular forms of activities of economic administration organs in selected areas of the economy. They confirm the specific nature of certain legal acts. Therefore, another challenge should be to develop a comprehensive scheme and introduce a uniform conceptual apparatus that would facilitate their full comprehension.

However, the legislator's attention should be drawn to the existence of excessively complex legal provisions, with the recommendation that there should be greater precision and transparency, and the development of uniform concepts to form the basis of legal science.

\section{Literature}

Banasiński C., Publicznoprawne aspekty ochrony konkurencji, in: Prawo gospodarcze. Zagadnienia administracyjnoprawne, Warszawa 2007.

Bar L., Publiczna subsydiarna działalność w gospodarce rynkowej. Wybrane zagadnienie prawne, "Państwo i Prawo” 1994.

Biegeleisen L.W., Teoria i polityka przedsiębiorstw publicznych samorzqdu terytorialnego i państwa, Warszawa 1931.

Bigo T., Ewolucja prawa przemysłowego, “Państwo i Prawo” 1947.

law) and "publiczne prawo gospodarcze" (public business law). From a theoretical point of view, the term "public" indicates the place of this law more closely in the legal system and more fully reflects its essence and the objectives of its regulation.

68 Without returning to the discussion on public business law, since this is not the subject of this study, it is worth referring to the discussion that took place in the pages of "Ruch Prawniczy, Ekonomiczny i Socjologiczny" in 1993; see in particular the arguments for distinguishing public business law - C. Kosikowksi, Idea prawa gospodarczego i jego działy, “Ruch Prawniczy, Ekonomiczny i Socjologiczny” 1993, p. 13, 17. 
BigoT.,Prawoadministracyjnepolskie-prawoprzemysłowe,Lwów1939. Boć J., W sprawie zakresu administracyjnego prawa gospodarczego, in: Prawo administracyjne, ed. J. Boć, Wrocław 2007.

Buzek J., Administracja gospodarstwa społecznego. Wykłady z zakresu nauki administracji i austriackiego prawa administracyjnego, LwówWarszawa 1913.

Chełmoński A., Realizacja dobra publicznego a ochrona interesów jednostki, in: Administracyjne prawo gospodarcze. Zagadnienia wybrane, eds A. Borkowski, A. Chełmoński, M. Guziński, K. Kiczka, L. Kieres, T. Kocowski, Wrocław 2000.

ChełmońskiA.,Swoistezasadyadministracyjnego prawagospodarczego, in: Administracyjne prawo gospodarcze, ed. L. Kieres, Wrocław 2005. Helczyński B., Komercjalizacja przedsiębiorstw państwowych na tle polskich przepisów prawnych, Warszawa 1929.

Huber E.R., Wirtschaftsverwaltungsrecht, vol. 1-2, Tubingen 1953/1954.

Kiczka K., Administracyjne akty kwalifikujq̨ce w działalności gospodarczej, Wrocław 2006.

Kiczka K., Prawo administracyjne gospodarcze w systemie prawa administracyjnego, in: Koncepcja systemu prawa administracyjnego, ed. J. Zimmermann, Warszawa, 2007.

Kieres L. ed., Środki prawne publicznego prawa gospodarczego, Wrocław 2007.

Kieres L., Administracyjne prawo gospodarcze, Wrocław 2005.

Kocowski T., Reglamentacja a regulacja, in: Administracyjne prawo gospodarcze, Regulacja rynku telekomunikacyjnego, eds M. Kulesza, A. Szpor, Warszawa 2005.

Kosikowski C., Idea prawa gospodarczego i jego działy, "Ruch Prawniczy, Ekonomiczny i Socjologiczny” 1993.

Lipowicz I., Europeizacja administracji publicznej, "Ruch Prawniczy, Ekonomiczny i Socjologiczny” 2008.

Lissoń P., Formy oraz instrumenty prawne działania organu regulacyjnego na przykładzie Prezesa Urzędu Regulacji Energetyki Instrumenty 
i formy prawne działania administracji gospodarczej, eds. B. Popowska, K. Kokocińska, Poznań 2009.

Longchamps F., Węzłowe problemy podstawowych pojęć prawa administracyjnego, "Państwo i Prawo" 1966.

Łaczkowski W., Ekonomiczne i socjalne prawa człowieka a dobro wspólne, Warszawa 2003.

Pawłowicz K., Prawne formy działania administracji gospodarczej-kierunki zmian i próba oceny, in: Instrumenty i formy prawne działania administracji gospodarczej, eds B. Popowska, K. Kokocińska, Poznań 2009.

Popowska B. ed., Funkcje współczesnej administracji gospodarczej, Poznań 2006.

Rabska T., Gospodarka rynkowa i jej zasady, Warszawa 1995.

Rabska T., Rozwój nauczania publicznego prawa gospodarczego - przyczynek do dyskusji, "PUG” 2005.

Rabska T., The Transit from a Centrally Planned Economy to a Market System, in: Public Administration in the Nineties: T-ends and Innovations, Wienna 1992.

Safjan M. ed., System prawa prywatnego. Prawo cywilne. Część Ogólna, Warszawa 2007.

Skoczny T., Stan i tendencje rozwojowe prawa administracji regulacyjnej w szczególności, in: Ius Publicum Europeum, Warszawa 2003.

Stelmach J., Brożek B., Załuski W., Dziesięć wykładów o ekonomii prawa, Warszawa 2007.

Strzyczkowski K., Gospodarka jako przedmiot regulacji prawnej, in: Prawo gospodarcze publiczne, Warszawa 2003.

Strzyczkowski K., Prawo gospodarcze publiczne, Warszawa 2007.

Strzyczkowski K., Środki i formy prawne organów administracji gospodarczej, in: Prawo gospodarcze publiczne, Warszawa 2011.

Strzyczkowski K., Zasada państwa sprawiedliwości społecznej jako zasada publicznego prawa gospodarczego, "Ruch Prawniczy, Ekonomiczny i Socjologiczny” 2007. 
Szpor A., Państwo a subsydiarnośc jako zasada prawa w UE i w Polsce, "Samorząd Terytorialny” 2001.

Szronnik A., Przedsiębiorstwo a region - relacje i współzależności rynkowe, "Samorząd Terytorialny" 2008.

Tokarczyk R., Jednostronność ekonomicznej analizy prawa, "Ruch Prawniczy, Ekonomiczny i Socjologiczny” 2007.

Trela A., Nowe formy działania ministra właściwego do spraw Skarbu Państwa w procesie komercjalizacji i prywatyzacji, in: Instrumenty i formy prawne działania administracji gospodarczej, eds B. Popowska, K. Kokocińska, Poznań 2009.

Ziembiński Z., Problematyka dogmatyczna nauk prawnych - rdzeń nauk szczegółowych, in: Szkice z metodologii szczegółowych nauk prawnych, Warszawa 1983.

Ziembiński Z., Szkice z metodologii szczegółowych nauk prawnych, Warszawa-Poznań 1983.

Zimmermann M., Nauka administracji i polskie prawo administracyjne, Part II, Poznań 1949. 